\title{
Survey of Raphia swamp forest, Republic of Congo, indicates high densities of Critically Endangered western lowland gorillas Gorilla gorilla gorilla
}

\author{
Hugo J. Rainey, Fortuné C. Iyenguet, Guy-Aimé F. Malanda \\ Bola Madzoké, Domingos Dos Santos, Emma J. Stokes \\ Fiona MAISELS and SAMANTHA STRINDBERG
}

\begin{abstract}
The Critically Endangered western lowland gorilla Gorilla gorilla gorilla is found at high density in the swamp forests of Lac Télé Community Reserve, northern Republic of Congo. Preliminary surveys for apes on the Reserve periphery in the 1990s indicated that this area may also contain high densities of apes and we wished to verify this. Using distance sampling methodology we surveyed $1,029 \mathrm{~km}^{2}$ of the south-eastern Reserve periphery including Raphia swamp forests. We recorded 1,021 ape nests along 21 $2-\mathrm{km}$ transects. Results indicated that ape density estimated from nest group density, excluding old and very old Raphia nests (which may decay slowly), was very high: 6.81 weaned apes $\mathrm{km}^{-2}$ (95\% confidence interval 3.93-11.84). Gorillas built most of the nests recorded: their density was estimated at 5.25 individuals $\mathrm{km}^{-2}$ (2.70-10.19). Most nests were constructed in Raphia swamp forest despite it covering only $25 \%$ of the study area. These are among the highest recorded densities of apes in Central Africa but, as nest decay rates in swamps are unstudied, we also estimated densities based on hypothetically slow nest decay rates and published data from other habitats. Gorilla densities may be linked to availability of monocotyledons as food and the natural protection from hunting offered by Raphia swamps. Gorilla density in swamp forest is spatially and temporally variable and surveys are required to estimate ape populations elsewhere in this habitat. Most Raphia swamps in Congo are unprotected, including the periphery of Lac Télé Community Reserve; protection and management are required to assure their continued availability for apes.
\end{abstract}

Hugo J. Rainey (Corresponding author), Emma J. Stokes, Fiona Maisels* and Samantha Strindberg Wildlife Conservation Society, 2300 Southern Boulevard, Bronx, NY 10460, USA. E-mail hrainey@wcs.org

Fortuné C. Iyenguet, Guy-Aimé F. Malanda and Bola Madzoké Congo Program, Wildlife Conservation Society, Brazzaville, Republic of Congo.

Domingos Dos Santos Ministère de l'Economie Forestière, Brazzaville, Republic of Congo.

${ }^{*}$ Also at: School of Biological and Environmental Sciences, University of Stirling, Stirling, UK.

Received 22 July 2008. Revision requested 16 September 2008.

Accepted 23 January 2009.
Keywords Chimpanzee, Congo, distance sampling, Gorilla gorilla, Lac Télé Community Reserve, monocotyledons, Pan troglodytes, Raphia, swamp forest

This paper contains supplementary material that can be found online at http://journals.cambridge.org

\section{Introduction}

S wamp forest in the Republic of Congo is known to $\checkmark$ contain high densities of Critically Endangered western lowland gorillas Gorilla gorilla gorilla. Surveys by Fay et al. (1989), Fay \& Agnagna (1992) and Blake et al. (1995) found high densities of gorillas in the Likouala swamps of northeast Congo, in areas that are now on the south-eastern and eastern periphery of the Lac Télé Community Reserve, which was gazetted in 2001 (Fig. 1). Additionally, swamp forest in the Sangha region of northern Congo also contains high densities of gorillas (Poulsen \& Clark, 2005; Malonga et al., 2007). Surveys and monitoring of large mammals in the Reserve and on its western periphery were carried out in 2002, 2004, 2005 and 2006. The surveys confirmed previous studies that the swamp forest contained high ape densities (Poulsen \& Clark, 2004; Malanda et al., 2005; Stokes et al., 2008). The importance of monocotyledonous plants in the diets of western lowland gorillas is well-known (Sabatier-Pi, 1977; Calvert, 1985; Tutin \& Fernandez, 1985; Carroll, 1988; Fay et al., 1989; Blake et al., 1995; Nishihara, 1995; Rogers et al., 2004). Much of the Likouala swamp forest has a sparse canopy with a dense understorey containing many monocotyledons such as Raphia spp., Aframomum angustifolium and Pandanus candelabrum. Fay et al. (1989), Fay \& Agnagna (1992) and Blake et al. (1995) mentioned the frequent use of Raphia spp. as food by gorillas. Blake et al. (1995) noted the virtual absence of gorillas in zones without Raphia.

Threats to the wildlife and forests of northern Congo are increasing. The imminent threats in Lac Télé Community Reserve and surrounding forests are construction of new roads, hydrocarbon prospecting on the south-west periphery, allocation of logging concessions and an increasing human population. The swamp forests of the Likouala region may be directly affected by these threats and it is imperative that baseline data on the wildlife populations of these swamps are 


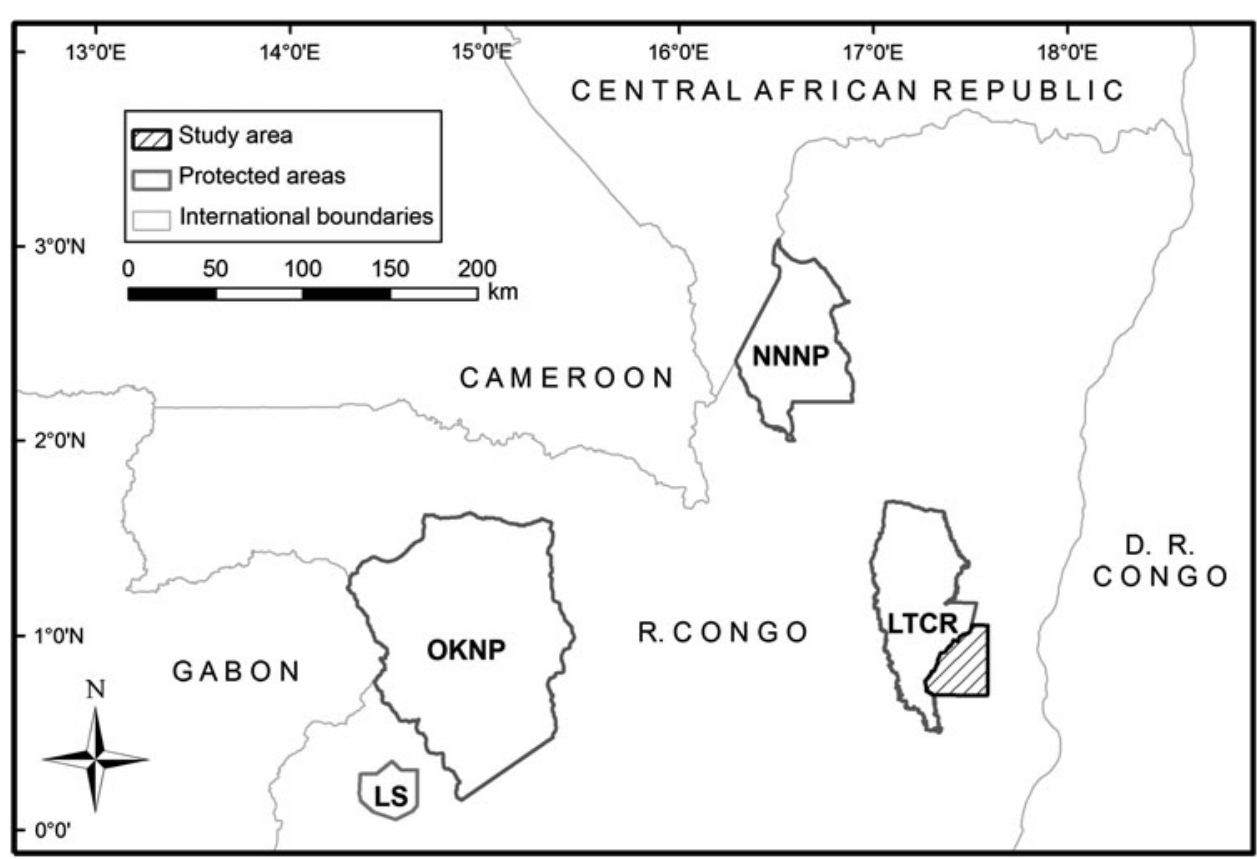

FIg. 1 Lac Télé Community Reserve (LTCR), the study area along the Batanga River, and other protected areas in northern Congo. NNNP, Nouabalé-Ndoki National Park; OKNP, OdzalaKokoua National Park; LS, Lossi Sanctuary. available. Given the suspected abundance of gorillas in Raphia swamps (Fay et al., 1989; Fay \& Agnagna, 1992; Blake et al., 1995), the recent upgrading of the threat status of the western lowland gorilla to Critically Endangered (IUCN, 2008), and that previous surveys of gorillas in the Raphia swamps of Congo were carried out before distance sampling methodology (Buckland et al., 2001) had become widely used for large mammal surveys in this region, we focused our survey efforts on the Raphia swamp forest south-east of Lac Téle Community Reserve (Fig. 1) to assess its importance for conservation of apes. This site is relatively accessible and is part of a larger potential Raphia zone (Appendix).

\section{Study area}

The Likouala swamps of northern Congo are part of the largest wetland in Africa, covering $62,500 \mathrm{~km}^{2}$ and straddling the Oubangui and Congo rivers, the border between the Republic of Congo and the Democratic Republic of Congo (DRC). Lac Télé Community Reserve is the sole protected area in swamp forest in the Republic of Congo. Conservation activities in the Reserve are managed in partnership between the Ministère de l'Economie Forestière and the Wildlife Conservation Society. Management planning focuses on the development of participative community management within traditional territories and the control of illegal hunting of protected species, including gorillas. Ninety percent of the Reserve comprises swamp forest (and a small area of savannah) that is flooded seasonally or permanently (see Poulsen \& Clark, 2004, for a more complete description of the Reserve). Swamp and seasonally flooded forest are dominated by dicotyledonous tree species, whereas the Raphia swamp forest of this study is almost entirely composed of Raphia spp. and some other herbaceous monocotyledons. The periphery of the Reserve is composed of similar habitat to that within its limits except for the terra firma mixed forest in managed logging concessions to the north-west and three zones of Raphia swamp to the north-east, east and south-east (Appendix), the latter of which is the focus of this article.

There are access constraints to the Likouala swamps: all travel is by boat and there is only one road connecting the swamps to other parts of the Likouala region. We therefore selected a relatively small area of $1,029 \mathrm{~km}^{2}$ named after the Batanga River (the south-eastern border of the Reserve), which had been partially surveyed by Fay \& Agnagna (1992) in 1989 and 1990. Satellite imagery indicates that the Raphia swamp extends far beyond our study area (Appendix).

\section{Methods}

\section{Survey design}

We used line transect distance sampling, analysed with Distance v. 5.0 (Thomas et al., 2006), to estimate densities of gorillas and chimpanzees Pan troglodytes. In line transect distance sampling observers traverse lines of aggregate length $L$ and the number $n$ of objects of interest is counted and the perpendicular distance to each is recorded. For indirect signs, such as great ape sleeping nests, production and decay rates are estimated and used to convert sign density into animal or animal group density (Buckland et al., 2001).

Distance v. 5.0 (Thomas et al., 2006) was used to place line transects systematically, with a random start within the 
survey area. Sampling effort represented a balance between obtaining sufficient survey precision and the financial and logistical constraints of conducting surveys across such a remote, inaccessible area. The sampling plan assumed a target coefficient of variation (CV) of $25 \%$ for density estimations of great ape nest groups. In calculating the total sampling effort required to attain density estimates with $25 \%$ precision we took encounter rates $n_{\mathrm{o}} / L_{\mathrm{o}}$ of great apes from baseline surveys conducted by Fay et al. (1989), Fay \& Agnagna (1992) and Poulsen \& Clark (2004). Total line transect length $L$ is calculated as follows (Buckland et al., 2001), where $C V_{t}(\hat{D})$ denotes the target $C V$ of $25 \%$ for the density estimate and dispersion parameter $b=3$, as recommended by Buckland et al. (2001):

$$
L=\left(\frac{b}{\left[C V_{\mathrm{t}}(\hat{D})\right]^{2}}\right) \times\left(\frac{L_{0}}{n_{0}}\right)
$$

All 21 transects (Appendix) were $2 \mathrm{~km}$ in length. Transects were placed perpendicular to the Batanga River to improve precision in abundance estimations as a result of vegetation gradients and any associated gradients in ape density.

During the survey the end of one transect and the beginning of the next were connected by guided recces that followed the path of least resistance through the forest rather than following a straight-line bearing (Hall et al., 1998; Walsh \& White, 1999). Guided recces do not deviate more than $40^{\circ}$ from the compass bearing, and may be used to assess the intensity and type of hunting if human paths are followed. Recces used in combination with line transects therefore provide an effective technique for establishing a baseline of wildlife and human activity at this site (Blake et al., 2007).

\section{Data collection}

The distance sampling line transect survey was conducted between March and May 2007 during the dry (low water) season. Methods broadly followed those suggested by White \& Edwards (2000). Three teams worked simultaneously across the survey zone and were composed of a principal observer responsible for nest sightings and a second observer who observed signs on the ground, including human sign. To minimize impact on the forest, permanent transects were not cut. A straight-line bearing through the forest was followed using machetes to open each transect just sufficient to enable the team to pass. A location, recorded with a global positioning system, was recorded at the beginning, midpoint and end of each transect. We noted all changes in forest type along the transect and position along the transect using a hip chain. We recorded all observations of great ape nests and dung, all other large mammal signs and all signs of human activity together with associated forest type, age of sign, vegetation type and hip chain distance. For all great ape nests we recorded the perpendicular distance between the transect and the centre of the nest. Here, we report only the results of the data collected on great apes.

\section{Forest types}

The four major forest types encountered were: (1) swamp forest, permanently flooded and dominated by the tree species Hallea stipulosa, Alstonia boonei, Sarcocephalus pobeguinii, Uapaca guineensis, Uapaca heudelotii, Uapaca paludosa, Macaranga schweinfurthii, Xylopia rubescens and Coelocaryon botryoides; (2) swamp forest with lianas; (3) forest flooded for only a few months of the year and dominated by Lophira alata, Chrysophyllum perpulchrum, U. heudelotii and Sterculia bequaertii and (4) Raphia swamp, primarily composed of Raphia spp. palms with dense undergrowth including some Pandanus spp. and A. angustifolium and a few trees. Raphia spp. palms were almost exclusively found in Raphia swamp, with few occurring in other forest types.

\section{Great apes}

We recorded construction type for all great ape nests (sensu Tutin et al., 1995) and, for those in trees, we recorded the height and species of tree in which the nest was built. We defined nest groups as all nests created by the same ape species and of the same age class created $\leq 50 \mathrm{~m}$ from each other. We classified each nest as definitely chimpanzee or gorilla if verifying signs (faeces, odour or hair) were present. Chimpanzees have not been recorded building ground nests in this region and therefore we attributed the nests on the ground to gorillas and any associated arboreal nests of the same age class as nests on the ground also to gorillas (Tutin \& Fernandez, 1984). For the remaining nests in trees we followed Tutin et al. (1995): for those tree nests for which the nest-building ape species could not be verified by associated signs we recorded the species as ape. Nest age and construction definitions were based on Tutin \& Fernandez (1984).

\section{Density estimates}

Distance v. 5.0 (Thomas et al., 2006), incorporating group size data, was used to estimate encounter rate, detectability, density and abundance of gorillas and chimpanzees. If all nests located on the line were detected with certainty, then the density of great ape nest groups in the study area surveyed, $D_{s}$, is estimated as (Buckland et al., 2001):

$$
\hat{D}_{\mathrm{s}}=\frac{n \hat{f}(0)}{2 L}
$$

where $\hat{f}(0)$ is the probability density function of the perpendicular distances evaluated at zero distance and 
$n / L$ is the encounter rate. $\hat{f}(0)$ can be interpreted as $1 / \hat{\mu}$, where $\hat{\mu}$ is referred to as the effective strip half-width and corresponds to the perpendicular distance from the transect line within which the number of undetected groups (distance to nest group is from the centre of the group) is equal to the number of groups detected beyond it. Two times the effective strip half-width multiplied by $L$ gives the effective area surveyed. The density of great apes $\hat{D}$ is obtained by dividing the estimated nest group density $\hat{D}_{\mathrm{s}}$ by the estimated production rate $\hat{p}$ and mean time to decay $\hat{c}$ and multiplying by the mean nest group size $\bar{s}$ (calculated from fresh or recent nests only). The density of nest groups and great apes is multiplied by the surface area $A$ of the study area to obtain the corresponding abundance estimate $\hat{N}_{\mathrm{s}}$ or $\hat{N}$, respectively. To improve model fit, data were grouped into distance intervals for analysis. Model selection was based on Akaike's information criterion (Burnham \& Anderson, 2002) and the results of the $\chi^{2}$ goodness-of-fit test were also considered.

\section{Production and decay rates for ape nests}

For our principal analysis we used a nest decay time of 91.5 \pm SE 1.67 days for both gorillas and chimpanzees and a nest production rate of $1.09 \pm$ SE 0.05 per day obtained from extensive line transect surveys conducted in Nouabalé-Ndoki National Park c. $175 \mathrm{~km}$ to the north-west (Morgan et al., 2006). This sampling error was incorporated into the calculation of confidence intervals. We know little about the decay rate of ape nests made from Raphia and it is possible that Raphia nests decay far more slowly than nests made from other vegetation (Blake et al., 1995; F. C. Iyenguet, pers. obs.; R. Kormos, unpubl. data). To obtain a conservative estimate we therefore included only fresh and recent Raphia nests for all the analyses (and all nests made with other plant species). Additionally, we explored the influence of nest decay rate on our estimations by applying a range of published decay rates (19.2-170 days) for ape nests from other sites and studies in Africa (Tutin \& Fernandez, 1984; Tutin et al., 1995; Brugière \& Sakom, 2001; Matthews \& Matthews, 2004) and a systematic series of hypothetical slow (200-600 days) decay rates, comparing these to our initial estimate.

\section{Results}

A total of 1,021 ape nests in 195 groups were recorded along the $42 \mathrm{~km}$ of 21 transects. The following analysis is based on 680 fresh and recent Raphia nests and all nests of other plant species occurring in 141 groups. Of these nests we positively identified 494 gorilla nests in 83 groups. Based on these data our principal analysis estimated great ape density as 6.81 weaned individuals $\mathrm{km}^{-2}$ (95\% confidence intervals, CI, 3.93-11.84) and gorilla density as 5.25 weaned individuals $\mathrm{km}^{-2}$ (95\% CI 2.70-10.19 Table 1, Fig 2). Gorilla density estimates for our results, based on published or hypothetical nest decay rates, range from a minimum of 0.80 individuals $\mathrm{km}^{-2}$ (95\% CI 0.41-1.54; hypothetical decay rate of 600 days) to 25.00 individuals $\mathrm{km}^{-2}$ (95\% CI 12.95-48.24; published decay rate of 19.2 days; Tables $2 \& 3$ ). Numbers of chimpanzee and unidentified ape nests were too low to permit density estimation for either allocation scenario; distance sampling requires at least $60-80$ objects per stratum (objects in this case are ape nest groups) to fit a detection function reliably and to obtain a reliable estimate of density (Buckland et al., 2001).

Seven habitat types were recorded during the survey (Fig. 3). Nests were constructed in all except grass savannah along rivers but most nests $(64.0 \%)$ were constructed in Raphia swamp where nest frequency was disproportionately higher than the abundance of this habitat $\left(\chi^{2}=849.451\right.$, $\mathrm{df}=3, \mathrm{P}<0.0001$; Fig. 3).

Human activity indices calculated from recce surveys were low (encounter rate 0.19 sign $\mathrm{km}^{-1}$ of transect) and the interpolated map of human activity shows it to be peripheral to the main area of high ape density and closest to navigable rivers (Fig. 4).

\section{Discussion}

Our results indicate that very high densities of great apes (5.25 gorillas $\mathrm{km}^{-2}$ and 6.81 great apes $\mathrm{km}^{-2}$, based on

TABLe 1 Ape densities and abundance estimates in the study area along the Batanga River (Fig. 1) using decay rates from Morgan et al. (2006), with total survey effort in $\mathrm{km}(L)$, number of observations (n) of nest groups and nests, encounter rate $\mathrm{km}^{-1}(n / L)$ of nest groups and nests, nest group density $\mathrm{km}^{-2}\left(\hat{D}_{s}\right)$, individual density $\mathrm{km}^{-2}(\hat{D}$, with $95 \%$ confidence interval), and abundance $(\hat{N}$, with $95 \%$ confidence interval), and coefficient of variation (\%CV) for density. Density and abundance estimates for chimpanzees and unidentified apes were not calculated as numbers of confirmed nests observed were so low. Old and very old Raphia nests were excluded from the calculations (see text for further details).

\begin{tabular}{llllllll} 
Species & $L(\mathrm{~km})$ & $n$ (nests) & $n / L$ (nests) & $\hat{D}_{\mathrm{s}}$ & $\hat{D}(95 \% \mathrm{CI})$ & $\hat{N}(95 \% \mathrm{CI})$ & $\% \mathrm{CV}$ \\
\hline Ape & 42 & $140(732)$ & $3.33(17.43)$ & 126.61 & $6.81(3.93-11.84)$ & $7,647(4,044-12,183)$ & 26 \\
$\begin{array}{l}\text { Gorilla Gorilla gorilla gorilla } \\
\quad \text { (confirmed nests) }\end{array}$ & 42 & 83 & 1.97 & 91.41 & $5.25(2.70-10.19)$ & $5,402(2,778-10,486)$ & 33 \\
Chimpanzee Pan troglodytes & 42 & 9 & 0.21 & & & & \\
Unidentified ape & 42 & 5 & 0.12 & & & \\
\hline
\end{tabular}




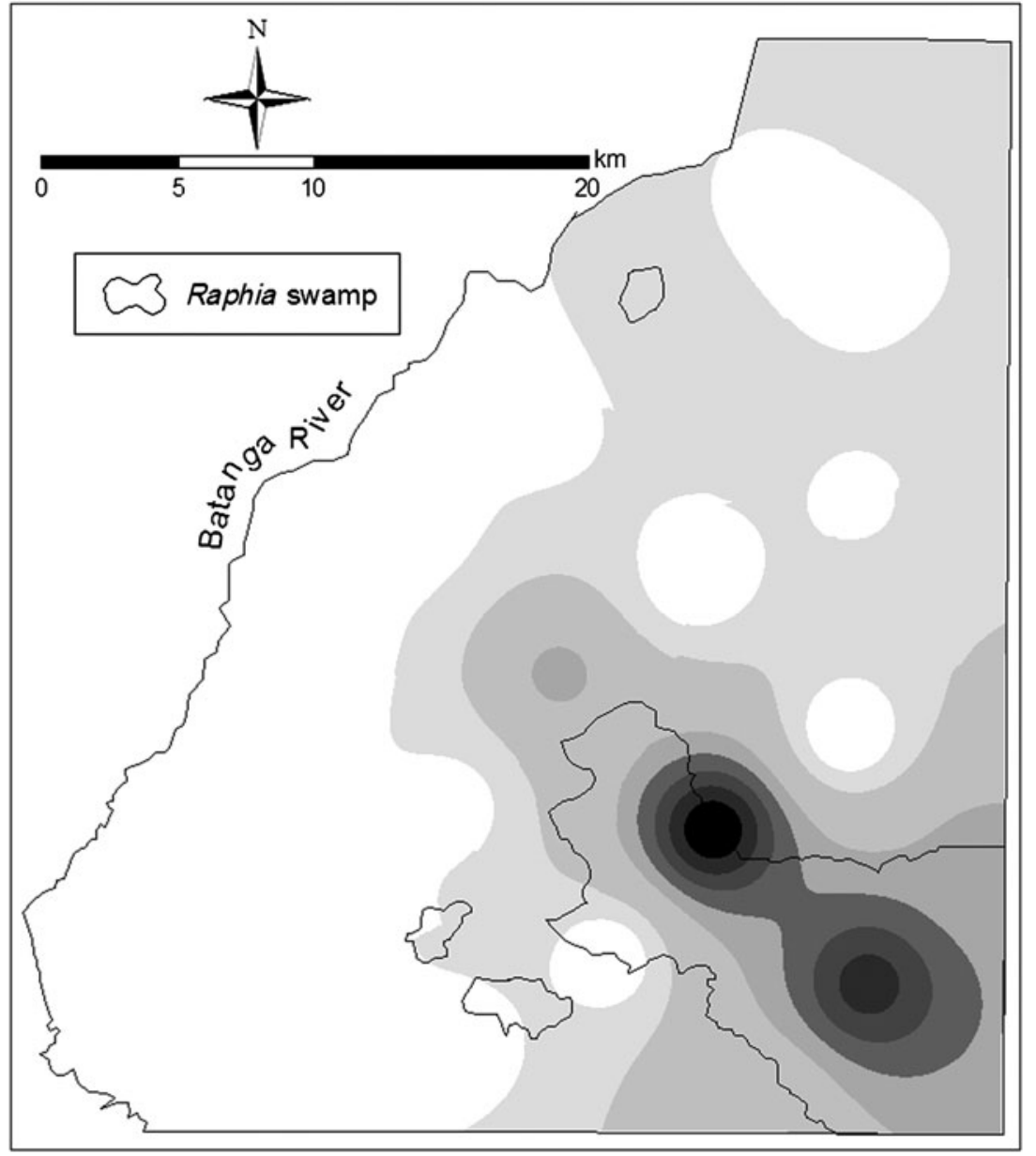

FIG. 2 Interpolated map of gorilla nest group density in the study area along the Batanga River (Fig. 1). Interpolated values of nest group density were made across a surface from a series of points (the centroid of each transect) by using the Inverse Distance Weighted technique in the Spatial Analyst extension of the geographical information system ArcView v. 3.2 (ESRI, Redlands, USA). a published nest decay rate of 91.5 days; Morgan et al., 2006) occur in the survey area giving an estimated potential population of 5,402 gorillas and 7,008 great apes (Table 1 ) in a relatively small area of $1,029 \mathrm{~km}^{2}$. This density is much higher than the previous figure estimated from a small part of this study site (Fay \& Agnagna, 1992) and is one of the highest density estimates ever calculated for great apes and for gorillas (Table 1). See Poulsen \& Clark (2004, 2005), Maisels et al. (2006), Morgan et al. (2006), Malonga et al. (2007) and Stokes et al. (2008) for comparison of density estimates from other sites in Central Africa. Human activity was low throughout the whole survey area (Fig. 4).

TABLE 2 Gorilla density and abundance estimates (with 95\% confidence intervals) calculated using nest density from this study and nest decay rates (in decreasing order of magnitude) from published studies. Our principal analysis (from Table 1) is in bold.

\begin{tabular}{|c|c|c|c|c|}
\hline Site & $\begin{array}{l}\text { Mean decay } \\
\text { time (days) }\end{array}$ & $\begin{array}{l}\text { Density } \\
(95 \% \mathrm{CI})\end{array}$ & $\begin{array}{l}\text { Population } \\
(95 \% \mathrm{CI})\end{array}$ & Habitat (reference) \\
\hline $\begin{array}{l}\text { Ngotto, SW Central } \\
\text { African Republic }\end{array}$ & 170 & $2.82(1.46-5.45)$ & $2,905(1,505-5,608)$ & $\begin{array}{l}\text { Semi-deciduous forest (Brugière \& } \\
\text { Sakom, 2001) }\end{array}$ \\
\hline $\begin{array}{l}\text { Campo Ma'an, SW } \\
\text { Cameroon }\end{array}$ & 133 & $3.61(1.87-6.96)$ & $3,714(1,924-7,168)$ & $\begin{array}{l}\text { Semi-deciduous forest (Matthews \& } \\
\text { Matthews, 2004) }\end{array}$ \\
\hline Ndoki, N Congo & 91.5 & $5.25(2.70-10.19)$ & $5,402(2,778-10,486)$ & Semi-deciduous forest (Morgan et al., 2006) \\
\hline Lopé, Gabon & 78 & $6.15(3.19-11.88)$ & $6,332(3,281-12,222)$ & Semi-evergreen forest (Tutin et al., 1995) \\
\hline Belinga, NE Gabon & 61.7 & $7.78(4.03-15.01)$ & $8,005(4,147-15,451)$ & Semi-evergreen forest (Tutin \& Fernandez, 1984) \\
\hline $\begin{array}{l}\text { Campo Ma'an, SW } \\
\text { Cameroon }\end{array}$ & 57 & $8.42(4.36-16.25)$ & $8,665(4,489-16,725)$ & $\begin{array}{l}\text { Semi-deciduous forest (Matthews \& } \\
\text { Matthews, 2004) }\end{array}$ \\
\hline Belinga, NE Gabon & 52.7 & $9.11(4.72-17.58)$ & $9,372(4,856-18,090)$ & Semi-evergreen forest (Tutin \& Fernandez, 1984) \\
\hline Belinga, NE Gabon & 50.9 & $9.43(4.88-18.20)$ & $9,704(5,027-18,729)$ & Semi-evergreen forest (Tutin \& Fernandez, 1984) \\
\hline Belinga, NE Gabon & 19.2 & $25.00(12.95-48.24)$ & $25,725(13,328-59,652)$ & Semi-evergreen forest (Tutin \& Fernandez, 1984) \\
\hline
\end{tabular}


TABLE 3 Extrapolated gorilla density and population estimates (with 95\% confidence intervals) using nest density from this study and hypothetically slow nest decay rates, incorporating only fresh and recent nests in the model.

\begin{tabular}{llc}
\hline $\begin{array}{l}\text { Mean decay } \\
\text { time (days) }\end{array}$ & Density (95\% CI) & Population $(95 \%$ CI) \\
\hline 600 & $0.80(0.41-1.54)$ & $823(426-1,589)$ \\
550 & $0.87(0.45-1.68)$ & $898(465-1,733)$ \\
500 & $0.96(0.50-1.85)$ & $988(512-1,907)$ \\
450 & $1.07(0.55-2.06)$ & $1,098(569-2,118)$ \\
400 & $1.20(0.62-2.32)$ & $1,235(640-2,383)$ \\
350 & $1.37(0.71-2.65)$ & $1,411(731-2,724)$ \\
300 & $1.60(0.83-3.09)$ & $1,646(853-3,178)$ \\
250 & $1.92(0.99-3.71)$ & $1,976(1,024-3,813)$ \\
200 & $2.40(1.24-4.63)$ & $2,470(1,279-4,767)$ \\
\hline
\end{tabular}

Ape nest production and decay rate

We recognize that where nest decay rates are used to estimate density they should optimally be carried out concurrently with a study of nest decay rates and that Raphia nest decay rates are poorly known. Nest decay rates in other published studies of African apes vary widely (Table 2) and in Kalimantan, Indonesia, orangutan nests have been found to persist for up to 600 days (Mathewson et al., 2008). However, this latter study included recording nests after leaves have fallen off, a total of $38 \%$ of decay time (S. Wich, pers. comm.). Nests of this condition were not recorded by White \& Edwards (2000), the method used in this study. The use of palms by chimpanzees has been reviewed, but production and decay rates of palm-constructed nests have

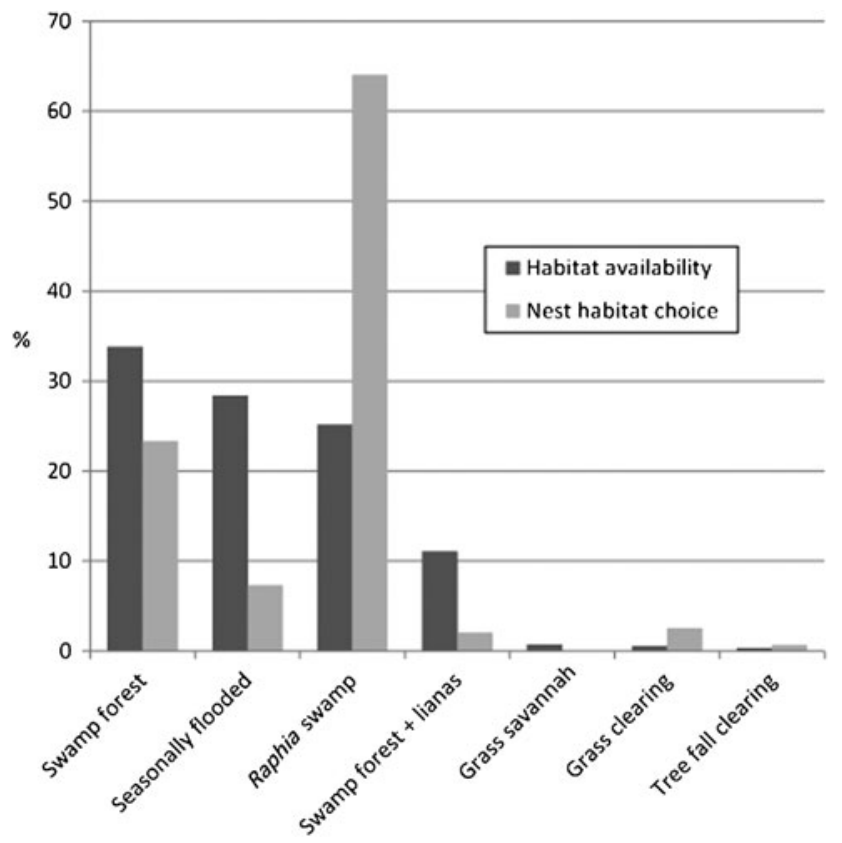

FIG. 3 Percentage of habitat types in the study area along the Batanga River (Fig. 1) compared with habitat nesting preference of great apes. not been studied (Humle \& Matsuzawa, 2004). Raphia is a typical construction material for chairs and roofing in the region and is known to be relatively resilient to rotting. Our approach of excluding old and very old Raphia nests for the analysis is conservative. This eliminated older Raphia nests that could have inflated our density estimates, and only $14.5 \%$ of the nests that were included in the analysis were made from Raphia. Thus, a large proportion of the nests were made of materials with a decay rate that is likely to be close to that published in previous studies (Morgan et al., 2006). Fresh nests are categorized by the presence of odour and dung and recent nests by green vegetation, no odour and possibly dung (Tutin \& Fernandez, 1984). It is thus highly unlikely that nests that are many months old would have been recorded in these categories. The inclusion of the standard error of nest decay rate from Morgan et al. (2006), which tends to increase the range of the confidence intervals (Plumptre, 2000), had limited influence.

We calculated densities using decay rates from other published studies (Table 2) but even when calculated using the slowest published decay rates, the lowest density estimate for the Batanga swamps of 2.82 individuals $\mathrm{km}^{-2}$ (95\% CI 1.46-5.45) is still high. Using hypothetically slow decay rates of up to 600 days (Table 3 ) the estimated gorilla density of 0.80 individuals $\mathrm{km}^{-2}$ is still moderately high. However, we did not carry out a simultaneous study of nest decay rates and nest production rates (see Bradley et al., 2008 , for a recent study of nest production rates) and there may be some bias contributed to the density estimate from both these factors. We recommend incorporating a Raphiaspecific nest decay study in subsequent ape surveys in this area to reduce bias from this source.

\section{Gorilla habitat preference and density variation}

The apes in Batanga were concentrated in an area of Raphia swamp in the south-east of the survey zone (Fig. 2) covering $25 \%$ of the surface area. On three transects we recorded no nests and, on four transects, $>100$ nests. However, the confidence intervals of the density estimate in our study are comparable to those found elsewhere (Table 1; Poulsen \& Clark, 2004). Williamson \& Usongo (1996) also found that Raphia swamp harboured high densities of gorillas and Maisels \& Cruickshank (1996) noted high densities of both ape species in marsh forest.

The high densities we found may be related to the amount of food available for gorillas in Raphia swamp, a preference already noted by Fay et al. (1989), Fay \& Agnagna (1992), Blake et al. (1995) and Bermejo (1999), who observed that gorillas eat almost all terrestrial monocotyledon species whatever the morphology. Monocotyledons are known to be only lightly chemically defended, if at all (Rhoades \& Cates, 1976; Waterman, 1984), and are favoured 


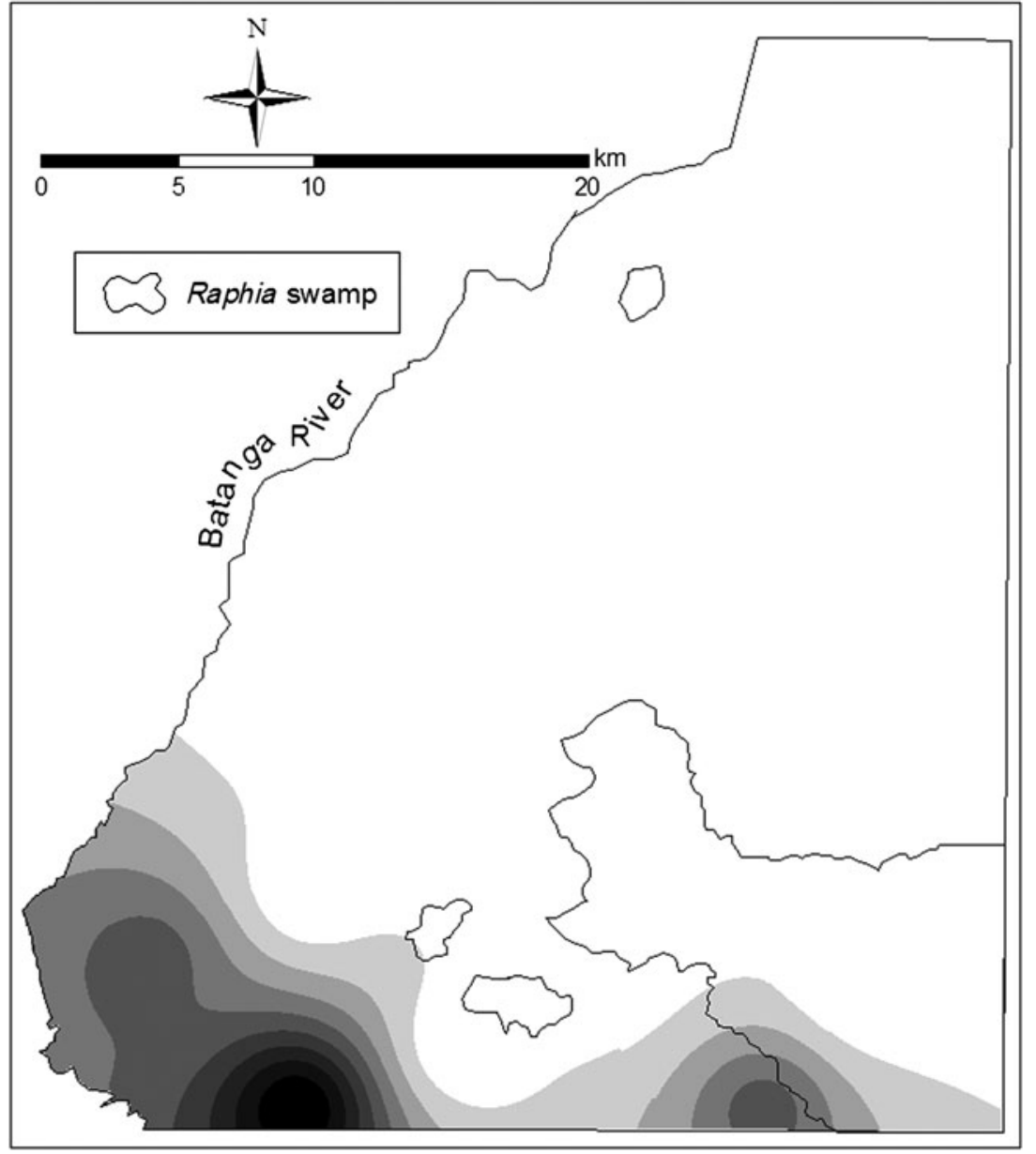

FIG. 4 Interpolated map of encounter rate of human activity signs (paths and machete cuts) from guided reconnaissance surveys in the study area along the Batanga River (Fig. 1). Interpolation was as described in the caption to Fig. 2, using human activity signs as the points. by many generalist herbivores, not only gorillas. The yearround availability of monocotyledons in Raphia swamps may be attractive to gorillas and they may be sedentary in this habitat. This is in contrast to the gorillas in the swamp and terra firma forest of Lac Télé Community Reserve that apparently move between habitats, possibly because of fluctuating fruit availability (Poulsen \& Clark, 2004; Malanda et al., 2005). Gorilla densities in swamp forest vary both spatially and temporally (Fay et al., 1989; Fay \& Agnagna, 1992; Blake et al., 1995; Williamson \& Usongo, 1996; Poulsen \& Clark, 2004; Malanda et al., 2005). Thus, surveys should be stratified by habitat where possible and conservation land-use planning should take into account year-round habitat requirements.

\section{Conservation management}

The study site is important for apes and also elephants Loxodonta africana and other primates including red colobus Piliocolobus oustaleti (data collected simultaneously with this study; Malanda et al., 2007). More than 15 years after the survey of Fay \& Agnagna (1992) the gorilla population in Batanga swamp remains high, perhaps because the site is inaccessible and remote. The Likouala swamps are the only remaining forest in the Congo Basin $>70 \mathrm{~km}$ from roads and the sole unprotected area $>50 \mathrm{~km}$ from roads (Blake et al., 2007). However, data from 2008 suggest that the remaining Raphia swamp may be affected by human activities (G.-A.F. Malanda \& F.C. Iyenguet, pers. obs.). The caveat of Blake et al. (2007) that, in some areas, rivers may confound the effect of roads as a proxy for isolation may therefore be correct. Currently, most Raphia swamp in northern Congo is found outside existing protected areas (Appendix). As the habitat is difficult to penetrate and gorillas are threatened by ebola and hunting elsewhere (Walsh et al., 2003, 2005; Leroy et al., 2004; Tutin et al., 2005; Bermejo et al., 2006; Rizkalla et al., 2007), this Raphia swamp should be protected. There is potential to enlarge the limits of Lac Télé Community Reserve taking into account the year-round habitat requirements of gorillas.

\section{References}

Bermejo, M. (1999) Status and conservation of primates in Odzala National Park, Republic of the Congo. Oryx, 33, 323-331.

Bermejo, M., Rodriquez-Teijeiro, J.D., Illera, G., Barroso, A., Vila, C. \& Walsh, P. (2006) Ebola outbreak killed 5000 gorillas. Science, 314, 1564. 
Blake, S., Rogers, E., Fay, J.M., Ngangoué, M. \& Ebeke, G. (1995) Swamp gorillas in northern Congo. African Journal of Ecology, 33, 285-290.

Blake, S., Strindberg, S., Boudjan, P., Makombo, C., Bila-Isia, I., Ilambu, O. et al. (2007) Forest elephant crisis in the Congo Basin. PLoS Biology, 5(4), e111. Doi: 10.1371/ journal.pbio.0050111.

Bradley, B.J., Doran-Sheehy, D.M. \& Vigilant, L. (2008) Genetic identification of elusive animals: re-evaluating tracking and nesting data for wild western gorillas. Journal of Zoology, 274, 333-400.

Brugière, D. \& S A ком, D. (2001) Population density and nesting behaviour of lowland gorillas (Gorilla gorilla gorilla) in the Ngotto Forest, Central African Republic. Journal of Zoology, 255, 251-259.

Buckland, S.T., Anderson, D.R., Burnham, K.P., Laake, J.L., Borchers, D.L. \& Thomas, L. (2001) Introduction to Distance Sampling: Estimating Abundance of Biological Populations, 2nd edition. Oxford University Press, Oxford, UK.

Burnham, K.P. \& Anderson, D.R. (2002) Model Selection and Inference: A Practical Information-theoretic Approach, 2nd edition. Springer, New York, USA.

Calvert, J. (1985) Food selection by western gorillas (G. g. gorilla) in relation to food chemistry. Oecologia, 65, 236-246.

CARROLL, R. (1988) Relative density, range extension, and conservation potential of the lowland gorilla (Gorilla gorilla gorilla) in the Dzanga-Sangha region of south-western Central African Republic. Mammalia, 52, 309-323.

FAY, J.M. \& AGNAGNA, M. (1992) Census of gorillas in northern Republic of Congo. American Journal of Primatology, 27, 275-284.

Fay, J.M., Agnagna, M., Moore, J. \& Oко, R. (1989) Gorillas (Gorilla g. gorilla) in the Likouala swamp forests of North Central Congo: preliminary data on populations and ecology. International Journal of Primatology, 10, 477-486.

Hall, J.S., White, L.J.T., Inogwabini, B.-I., Omari, I., Morland, H.S., Williamson, E.A. et al. (1998) Survey of Grauer's gorillas (Gorilla gorilla graueri) and Eastern chimpanzees (Pan troglodytes schweinfurthi) in the Kahuzi-Biega National Park lowland sector and the adjacent forest in Eastern Democratic Republic of Congo. International Journal of Primatology, 19, 207-235.

Humle, T. \& Matsuzawa, T. (2004) Oil palm use by adjacent communities of chimpanzees at Bossou and Nimba Mountains, West Africa. International Journal of Primatology, 25, 551-581.

IUCN (2008) 2008 IUCN Red List of Threatened Species. IUCN, Gland, Switzerland. Http://www.iucnredlist.org [accessed 19 August 2009].

Leroy, E.M., Rouquet, P., Formenty, P., Souquière, S., Kilbourne, A., Froment, J.-M. et al. (2004) Mutiple ebola virus transmission events and rapid decline of central African wildlife. Science, 303, 387-390.

Maisels, F.G., Aа'ва, R., Авitsi, G., Bеснем, M., Bout, N., Kuent, H. et al. (2006). Gabon's National Park system: baseline wildlife and human impact surveys. In Conservation Without Borders (Abstracts). Contributed Oral Presentations. Society for Conservation Biology Annual Conference, San Jose, USA.

Maisels, F.G. \& Cruickshank, A.J. (1996) Inventaire et recensement des grands mammiferes dans le Reserve de Faune de Conkouati. Unpublished Report. UICN/Projet Conkouati, Brazzaville, Republic of Congo.

Malanda, G.-A.F., Iyenguet, F.C. \& Bola, Madzoké (2007) Recensement des grands mammifères à l'est de la Batanga. Unpublished Report. Wildlife Conservation Society, Brazzaville, Republic of Congo.

Malanda, G.-A.F., Iyenguet, F.C., Bola, Madzoké, Dongo, S., Molombe Moké, M. \& Rainey, H.J. (2005) Etudes des grands mammiferes de la Bailly 2005. Unpublished Report. Wildlife Conservation Society, Brazzaville, Republic of Congo.

Malonga, R., Kiminou, F.A.O. \& NGanga, I. (2007) Recensement et distribution des grands mammifères et activités humaines dans l'UFA Pikounda (Nord-Congo). Unpublished Report. Wildlife Conservation Society, Brazzaville, Republic of Congo.

Mathewson, P.D., Spehar, S.N., Meijaard, E., Nardiyono, Purnomo, S ASmirul, A. et al. (2008) Evaluating orangutan census techniques using decay rates: implications for population estimates. Ecological Applications, 18, 208-221.

Matthews, A. \& Matthews, A. (2004) Survey of gorillas (Gorilla gorilla gorilla) and chimpanzees (Pan troglodytes troglodytes) in south-western Cameroon. Primates, 45, 15-24.

Morgan, D., Sanz, C., Onononga, J.R. \& Strindierg, S. (2006) Ape abundance and habitat use in the Goualougo Triangle, Republic of Congo. International Journal of Primatology, 27, $147-179$.

Nishinara, T. (1995) Feeding ecology of western lowland gorillas in the Nouabalé-Ndoki National Park, Congo. Primates, 36, 151-168.

Plumptre, A.J. (2000) Monitoring mammal populations with line transect techniques in African forests. Journal of Applied Ecology, $37,356-368$.

Poulsen, J.R. \& Clark, C.J. (2004) Densities, distributions and seasonal movements of gorillas and chimpanzees in swamp forest, northern Congo. International Journal of Primatology, 25, 285-306.

Poulsen, J.R. \& Clark, C.J. (2005) Inventaire des ressources forestières de l'unité forestière d'aménagement de Pikounda (Nord Congo). Tome II: Recensement et distribution des grands mammifères et activités humaines. Unpublished Report. Wildlife Conservation Society, Brazzaville, Republic of Congo.

RhoAdes, D.F. \& CAtes, R.G. (1976) Towards a general theory of plant anti-herbivore chemistry. In Biochemical Interactions Between Plants and Insects. Recent Advances in Phytochemistry, Vol. 10 (eds J.W. Wallace \& R.L. Mansell), pp. 168-213. Plenum Press, New York, USA.

Rizkalla, C., Blanco-Silva, F. \& Gruver, S. (2007) Modeling the impact of ebola and bushmeat hunting on western lowland gorillas. EcoHealth, 4, 151-155.

Rogers, M.E., Abernethy, K., Bermejo, M., Cipolletta, C., Doran, D., McFarland, K. et al. (2004) Western gorilla diet: a synthesis from six sites. American Journal of Primatology, 64, 173-192.

Sabatier-Pi, J. (1977) Contribution to the study of the alimentation of lowland gorillas in the natural state, in Rio Muni, Republic of Equatorial Guinea (West Africa). Primates, 18, 183-204.

Stokes, E.J., Strindberg, S., Bakabana, P.C., Iyenguet, F.C., Malanda, G.-A., Bola, Madzoké et al. (2008) Spatial Modeling of Great Ape and Elephant Abundance at the Landscape Scale in Northern Republic of Congo. Unpublished Report. Wildlife Conservation Society, Brazzaville, Republic of Congo.

Thomas, L., Laake, J.L., Strindberg, S., Marques, F.F.C., Buckland, S.T., Borchers, D.L. et al. (2006) Distance 5.o. Release 2. Centre for Research into Ecological and Environmental Modelling, University of St Andrews, St Andrews, UK.

Tutin, C.E.G. \& Fernandez, M. (1984) Nationwide census of gorilla (Gorilla gorilla gorilla) and chimpanzee (Pan troglodytes troglodytes) populations in Gabon. American Journal of Primatology, 6, 313-336.

Tutin, C.E.G. \& Fernandez, M. (1985) Foods consumed by sympatric populations of Gorilla g. gorilla and Pan t. troglodytes in Gabon: some preliminary data. International Journal of Primatology, 6, 27-43.

Tutin, C.E.G., Parnell, R.J., White, L.J.T. \& Fernandez, M. (1995) Nest building by lowland gorillas in the Lopé Reserve, 
Gabon: environmental influences and implications for censusing. International Journal of Primatology, 16, 53-76.

Tutin, C., Stokes, E., Boesch, C., Morgan, D., Sanz, C., ReED, T. et al. (2005) Regional Action Plan for the Conservation of Chimpanzees and Gorillas in Western Equatorial Africa. Conservation International, Washington, DC, USA.

Walsh, P.D., Abernethy, K.A., Bermejo, M., Beyers, R., De Wachter, P., Akou, M.E. et al. (2003) Catastrophic ape decline in western equatorial Africa. Nature, 422, 611-614.

Walsh, P.D., Biek, R. \& Real, L.A. (2005) Wave-like spread of ebola Zaire. PLoS Biology, 3(11), e371. Doi: 10.1371/journal. pbio.0030371.

Walsh, P.D. \& White, L.J.T. (1999) What will it take to monitor forest elephant populations? Conservation Biology, 13, 1194-1202.

Waterman, P.G. (1984) Food aquisition and processing as a function of plant chemistry. In Food Acquisition and Processing in Primates (eds D.J. Chivers, B.A. Wood \& A. Bilsborough), pp. 177-211. Plenum Press, London, UK.

White, L.J.T. \& Edwards, A. (eds) (2000) Conservation Research in the African Rainforests. A Technical Handbook. Wildlife Conservation Society, New York, USA.

Williamson, E.A. \& Usongo, L. (1996) Survey of gorillas Gorilla gorilla and chimpanzees Pan troglodytes in the Reserve de Faune du Dja, Cameroon. African Primates, 2, 67-72.

\section{Appendix}

The appendix for this article is available online at http:// journals.cambridge.org

\section{Biographical sketches}

Hugo Rainey has studied African birds since 1996, was formerly Lac Télé Community Reserve project director and is a Wildlife Conservation Society (WCS) technical advisor in Cambodia. Fortuné IYENGUET has been an ecologist at the Reserve since 2001 and surveyed mammals in Odzala. GuY-Aimé MALANDA has been an ecologist at the Reserve since 2001, surveying fish and mammals in the Ndoki-Likouala landscape. Bola MADzoKé has monitored mammals and waterbirds in the Reserve and Ndoki-Likouala landscape since 1998. Domingos Dos S Antos has worked to conserve gorillas for 16 years and is now conservator in Nouabalé-Ndoki National Park. Емма STокеs worked for 10 years on African ape research and conservation, coordinating monitoring in Congo, and now coordinates monitoring for the WCS tiger programme. Fiona MAISELS is Monitoring Coordinator for WCS Central Africa and has worked in this region's forests since 1988. Samantha STRINDBERG provides conservation planning and statistical assistance to WCS field programmes. 